Vol.6(6), pp. 205-213, J uly 2014

DOI: $10.5897 /$ IJ SA2014.0526

Artic le Number: EB8663146629

ISSN 2006- 988x

Copyright (c) 2014

Author(s) retain the copyright of this artic le

International Journal of Sociology and

http://www.academic joumals.org/IJ SA

\title{
The tradition to donate among women in Javanese rural areas: Reciprocity, food exchange and monetization
}

\author{
Soetji Lestari \\ University General Sudirman Purwokerto Indonesia. \\ Received 4 January 2014; Accepted 23 June 2014
}

\begin{abstract}
In the history of the tradition to donate (Tradisi Nyumbang) in Javanese rural areas as reciprocity institution, food produce are the main form of gift. However, economic system has penetrated the social aspect of the tradition. Money use as the medium for donation replaced food produce is now a general practice in almost all villages. The research will show how women from underprivileged households in rural areas adhere to use food produce as social exchange tool in the tradition of donation. The produce itself has subjective meaning for the women rooted from the village culture and custom even if they are no longer involved in agricultural farming. The shift in women's work pattern also characterizes food consumption pattern of the village. Many instant foods have displaced local food existence. This tradition to donate will portray how the moral economic of women villagers is being constructed.
\end{abstract}

Key words: Reciprocity, food exchange, moral economy of the rural women.

\section{INTRODUCTION}

\section{Background of the study}

The concept of gift is a universal concept in various countries and it has been going on for long. The gift has various functions: economic, social, moral, religious, politic, law and esthetic; thus, it is called "total social phenomenon" (Mauss 1992). Therefore, examining concept of the gift means examining social phenomenon in many aspects, especially, the gift can either create and maintain social ties or undermine and destroy it (Komter 2005; Molm 2010). Understanding concept of the gift is understanding reciprocity social institution developing within the society. Belshaw (1981) states that to understand the economic system of a society using cultural and social analyses exchange institution is the only point to start. As a separate institution, exchange has broken through all social buildings and can be seen as society's binder. "Tradisi Nyumbang" (tradition to donate) is one of the forms of concept of gift developing in Javanese rural areas. It is mostly viewed as activities to help each other and mutual assistance of rural society. During the ceremonies of human life cycle, such as ceremony for birth, circumcision, marriage and death; neighbors, relatives and friends assist, either by donating their money or doing volunteer work. Through this tradition, social solidarity is built. In addition, the tradition also can be seen as economic signal and dynamic social symbols.

Therefore, the kiting between social and economic acts

E-mail: soetji_lestari@yahoo.co.id

Author a gree that this article rema in perma nently open access under the terms of the Creative Commons Attribution Lic ense 4.0 Intemational Lic ense 
characterizes the tradition of donation as a social institution of a village. As stated by Camerer (1988), gift can be seen as 'economic signals' and 'social symbols'. Rural household expenditure bare by rural households is getting heavier along with the development of market economic that turn money into something that is more important in every social transaction. This development has caused villagers' dependency on money to grow stronger and wider. In this case, woman appears to be the most "responsible" person for the change, because in social and cultural aspect, woman is the economic controller of a household (Abdullah 2001). In social transaction, however, such as the tradition of giving, woman is the important "social actor" who takes many roles.

Studies on women role in gift exchange have not been a focus in previous research including research done in Western society (Komter 2005). Since Mauss and Malinowski presented the concept of "the gift" as an important issue in anthropology study, the important question is what role does gender play in this gift exchange. Old anthropology studies assumed that woman has no relevant role in the gift exchange. Malinowski, however, admitted that woman took part in certain ceremonial acts, but did not mention woman activities in gift exchange, all the involved samples were men. After Malinowski, Levi-Strauss who gave more attention on gift exchange practice in several non-Western societies showed woman as the important tool for gift exchange. Women existence was showed as the basic of family relation system. In this case, men saw women as the object of gift exchange instead of the subject or actor. On the other side, some studies have showed clearly that women are not only give the gift to men - material or immaterial - but also the biggest receiver of the gift (Komter 2005). The same is shown in the tradition to donate in Javanese rural areas. In this case, women take most of the important parts, quantitatively (work, time and cost allocated) or qualitatively (related to the intensity of women involvement). In a celebration conducted at the village by an underprivileged household, these activities to donate are dominated by activity on how to distribute food production and consumption. Therefore, as mentioned in Geertz (1983) and Stoler's (1977) writing on autonomy of rural women, women have important role in social-collective activities of a ceremony; though it is a very stereotype role, which is related to food supply especially shopping, cooking and distributing food. Therefore, the biggest activity in a ceremony at the village is related to food supply. Food distribution is the strengthening of symmetrical and asymmetrical socialeconomic relationships, which is part of the reciprocity system.

The intensify pressure from money economy in the village that has characterized many social transactions does not immediately make women able to adapt themselves to money economic system. Generally, those women describe as the specific women workers at the village, are the subsistence or non-salary workers and they are willing to be paid with food. The economic moral of rural women is shown in this tradition to donate, how they conduct social and economic transactions within the penetration of money economic. It is in this context, understanding how the existence of women in the tradition to donate is needed in order to understand how social-economic transformation in the village takes place, especially the ones related to the change from subsistence economic system to market (money) economic system.

\section{Problem formulation}

Nowadays, villages undergo the growth of money culture and life orientation toward money. According to Heyzer (1986), agricultural commercialization process is an important pressure that changes organization and social institution of a village, including tradition to donate. In this case, rural women appear to be as the most "responsible" actors for the change, because in social and cultural aspect, woman is the economic controller of a household and doing social responsibilities in their household neighborhood. The social responsibility itself is a burden for rural women when it is faced with money economic culture, whereas they have been accustomed to subsistence economic culture. Therefore, this research is trying to examine how the tradition to donate among women in Javanese rural areas takes place under socialeconomic change, especially in facing money economic system that lead the villagers to act rationally and calculative.

\section{OBJECTIVE OF THE STUDY}

The research aims to analyze economic moral of rural women through the tradition to donate taking place under money economic pressure. As reciprocity institution, the gift/charity in the village has strong control in arranging and controlling society in exchange process, especially for women. This study also wants to see how food exchange takes place in the tradition to donate as a base of village economy (subsistence ethic).

\section{METHODOLOGY}

The study took place in Javanese rural areas, particularly in sub culture of Java- Banyumas. Java tribe is the biggest tribe in Indonesia. Javanese rural areas, up to now, are identified with poverty. In various social studies on poverty in South East Asia, Indonesia is mostly represented by poverty in Javanese rural areas having dense population. Moreover, according to Boeke (Husken 
Table 1. Change in the form of donation in Javanese rural area overtimes.

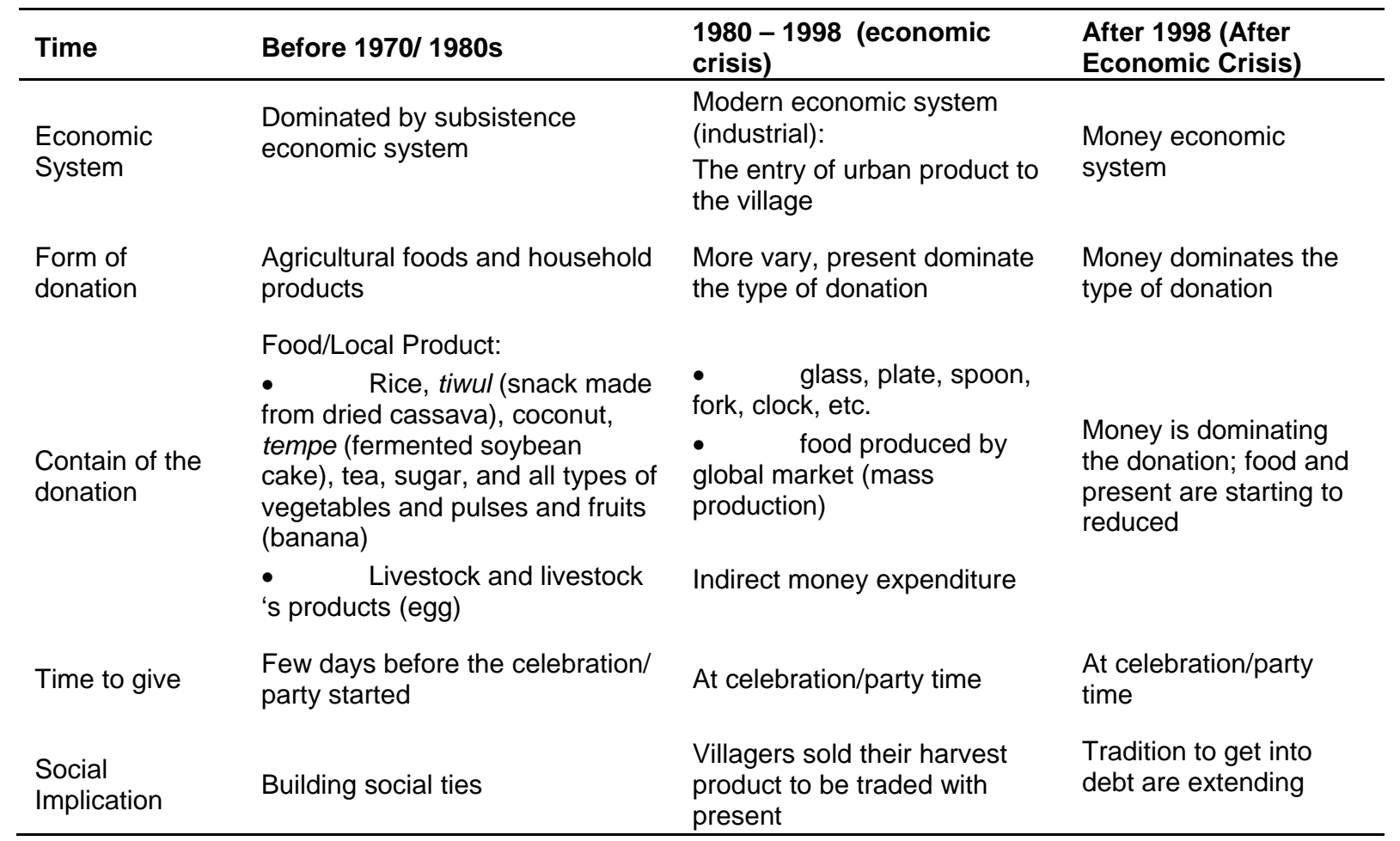

Source: Kutanegara, 2002 reprocessed by the researcher

1998), the central characteristic of "Eastern villages" including Java is communal-based social life. This research used constructivist paradigm as part of qualitative approach. It is based on assumption that the tradition to donate is a relative issue and local reality that is specifically constructed. Constructivism, by its follower, is considered as having the ability to uncover details of certain community culture by understanding its cultural setting scientifically with point of view of the examined subject. The subject point of view in this research is rural household mothers whom mostly are workers (maid), household mothers and workers of an eyelashes factory.

\section{RESULT}

\section{Donation institution in money economic system}

In the long history of the tradition to donate in Javanese rural areas as reciprocity institution, food produce is the main form of the donation. The village's economy is dominated by subsistence economic system; therefore, for the donation, they use food from agriculture and their own/household processed product (Kutanegara 2002). The donation sometimes can be in form of livestock such as chicken, goat or cow meat. In the past, this gift exchange tradition can be an incentive for agricultural product development. According to Belshaw's (1981) opinion, it happens, for example, in a village community
Hanuabada, an infertile land with low produce production. Exchange tradition in this area contains a competition and party with food distribution. Food distribution is the main incentive for agricultural product, and without the distribution, agricultural product will not be developed. In Java, along with the green revolution in agriculture in the 1970/1980's, many products from urban areas were flooding the village. Modern life started to penetrate to the village and change the consumption pattern of the society. They were no longer tied to the principle commodities. At that time, villagers, especially the youth, preferred to give present, particularly glassware (such as plates, glasses, bowls) or clock for the donation. Money economic system grew stronger, but not for the donation (for detail can be seen in table 1). Money was seen as a medium for economic transaction only and to pay for the commodity bought. Meanwhile, paying the service was considered awkward. Many villagers were unwilling to be "paid" for their voluntary work or service. Money as social transaction tool was limited for social donation, in which money is given by the rich to the poor which brings gaps between those two parties (the giver and the receiver).

1990s was a new era for the penetration of money economic system into social institution of donation in Java and this made money as a significant social change agent (Carruthers, 2005). At that time, most invitation for 
wedding and circumcision celebrations were inserted with message such as "Without being disrespect and with our deepest apology, ex-gratia should not be in the form of goods or wreath, thank you." The message does not state that the guest should not give money, but it gives clear signal that the inviter only receives money. The invitation also put an image of gifts crossed or an envelope. Most of Javanese societies considered the message as unethical and it became a major issue among them. The reason was that the basic of "donation" is volunteerism from the giver. However, when this type of message spread, the society finally rationalized money as social payment tool. Since then, donation has become a calculative social institution. Money is not only as an economic instrument but also social instrument and calculative social instrument (calculating character). (Polanyi, 1957; Simmel, 2004). Nowadays, that type of message no longer exists because money as social payment tool has been institutionalized through rural area. As stated by classical sociologist, Weber and Simmel, money can be an entry point to understand society's rationality process. When social institution of donation has monetized, donation turn into calculative and rational social institution.

The phenomenon from this tradition to donate as economic transaction is the emergence of profit/loss term to determine the success of conducting a party valued from the amount of donation gained. This is a general phenomenon taking place when conducting a party in Javanese rural areas as showed by Kutanegara's (2002) research in Bantul, Yogyakarta Special Region and a research from Prasetyo (2012) in Subang West Java. There are many economic terms tied to each celebration, such as circumcision, profit, mantu ${ }^{1}$ receiving capital and mbesan $^{2}$ throwing the capital or "wedding celebration is opening the saving". It shows that tradition to donate has shifted into an economic medium. According to Kutanegara (2002), it indicates the shift in the meaning of a ceremony, which was as an express of gratitude for a situation and now become business and trade arena. Unconsciously, anyone who comes to a celebration is seen as buying a commodity. It also can be used as a sign that capitalism has deeply penetrated and become intensive in Javanese culture.

On the other side, in trade activities, Javanese societies familiar with an ancient philosophy "tuno satak,

\footnotetext{
${ }^{1}$ Mantu is a wedding celebration conducted by the bride family. The general norm in Javanese community is that the bride family conducts wedding celebration.

${ }^{2}$ Mbesan is a wedding celebration, particularly in Java-Banyumas, conducted by the family from the groom to be several days before the wedding ceremony. This celebration is different to the general Javanese societies. The groom's wedding celebration usually called ngunduh conducted after wedding celebration in the bride family. Therefore, mbesan, by some people outside Banyumas is considered as a medium to collect money for "serah-serahan (gifts for the bride)" to the bride. This serah-serahan usually consists of many goods and it is considered as mbuang modal (throwing the capital)
}

bathi sanak" (loss of money, but can gain friends). In simple meaning, tuno means loss and bati means gain/profit, two words with opposite meaning. Satak is type of small fish, which is used in the philosophy as a symbol of goods or money, sanak means brother or also relatives or friends who has special value or closeness. Therefore, literally, the philosophy means, "loss of money but the profit is gaining friends/brothers". It means that maintaining hospitality and friendship is more valuable than losing the money/goods (Hadihardjono 2011). In the context of donation, the philosophy mostly applies to the giver where household expenditure for donation is a lot, especially in celebration season, months that are considered good for conducting celebration. For them, maintaining social harmony is more important than prospering their family. Borrowing from Geertz's term "shared poverty", villagers prefer to be poor together than being unable to give to their neighbor. For most rural women, the burden for being unable to give is heavier than poverty burden. It is indicated by avoiding meeting the person whom they did not donates to or pretending not seeing them when they passed each other.

In the middle of monetization pressure that institutionalized the tradition to donate in Javanese rural areas which has taken place for a relatively long period, women (especially from underprivileged group) in Banyumas villages maintain to give food as their donation. It is shown with the existence of megari. Megari is a woman actor who controls the supply of food donation given by women guests and she then arrange return gift for them. The return gift used usually gained from the donation too. The next section will discuss how the tradition to donate among women in rural areas of Jawa-Banyumas builds social ties in the middle of pressure from money economic system and how moral principle built in reciprocity institution.

\section{Reciprocity in women face}

As mentioned by Mauss (1992), a gift will never be a "free" gift, without any obligation to return it, it is called potlatch. Potlatch defines by Mauss as an exchange gift. And clearly stated that it is categorized as a reciprocity gift. There are three obligation in Mauss's exchange theory. First, give a gift as the first step to make social relationship. Second, receive the gift as the acceptance of social ties. Third, return the gift with higher value to show social integrity (Koentjaraningrat 1980). The obligation in gift exchange is reciprocally in nature; therefore, the value of the gift generally will increase. The more expensive the gift the better, because the parties involved is in exchanged (give - receive - return). This attitude is mostly shown by women; because women are more intensive in neighborhood life.

The reciprocity principle stated by Mauss is also strongly held by society in Banyumas village. Every 


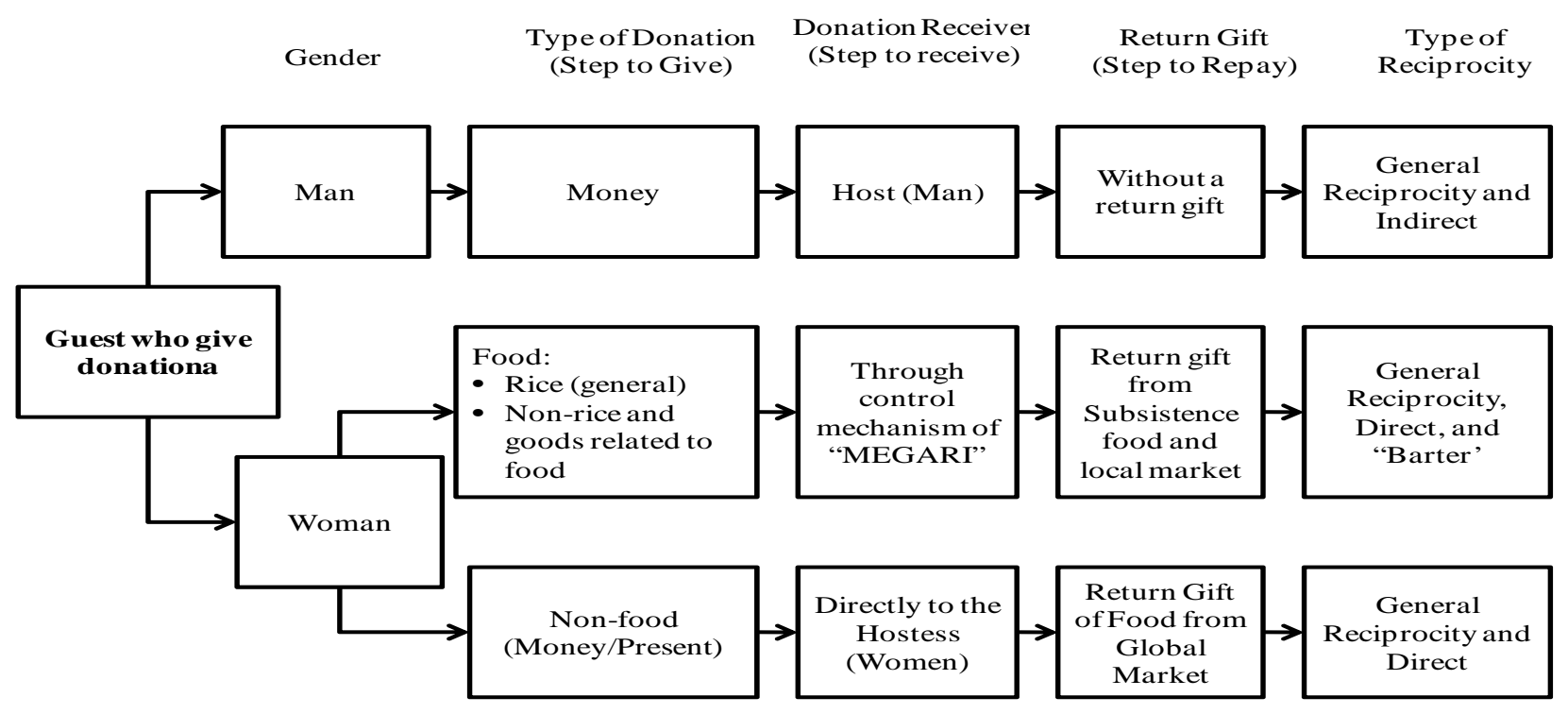

Figure 1. The mechanism of reciprocity principle in Java - Banyumasan Village.

donation received should be return properly according to the household condition of the person who holds the celebration. The mechanism of reciprocity principle, as seen in Figure 1, is determined mostly by gender and type or the amount of the donation. There are two types of reciprocity developed in the society, according to Sahlin (1974), generalized reciprocity and direct reciprocity. Generalized reciprocity is reciprocity exchange between individuals or groups without determining the time limit to return the gift. Villagers call this type of reciprocity as Gentenan. In this exchange, each party believes that they will give each other and that the goods gave or services provided will be repaid. In direct reciprocity, on the other hand, goods or services exchanged are having comparable value. Time to receive and return the gift, the amount and goods to be exchanged are pre-determined. The nature of this payment shows the exact time when someone receiving the payment or repay for the gift or activities conducted previously.

In the tradition to donate in Banyumasan village, the giver is representing individual unit instead of household unit; therefore, husband and wife give individually. This is in contrast to the phenomenon that takes place in urban society where donation is representing husband and wife in one household. Gender will determine the type of the donation. The general pattern of the donation is man usually gives money and woman gives food. It describes sexual-based work distribution pattern, which is very stereotype in society in general, man as the breadwinner and woman as household mother who takes care and arranges food consumption. For man, the type of donation involves money, which describes an established pattern. Money is identified with man who has rationality because money is a rationality tool (Simmel, 2004). The difference is only on the amount of money to be given that is determined by kinship and neighborhood ties. Mostly, man gives Rp. $10.000,00$ in average or between Rp. $5.000,00$ to Rp. $20.000,00$.

For woman, on the contrary, the type and form of donation will be more complex. The general pattern of the donation for women in rural society of Java-Banyumas is food. There are two categories of food, rice and non-rice. Rice is the general gift for woman with standard amount of two $\mathrm{kg}$. Rice is used to describe the pressure of tradition to donate. Nowadays, villagers strive to buy "Raskin" - type of rice provided by the government grant to help poor household - for the donation purpose. The rice has lower price compare to the general rice consumed. The price of general rice would be $\mathrm{Rp}$. $7.000,00$ per kg, while Raskin only Rp. $6.000,00$ per $\mathrm{kg}$. The Rp. 1.000,00 difference on price will mean a lot for poor household women. They can save Rp. 2.500,00 for one donation. If they received 3 to 5 invitations for a ceremony just in one day, the money saved for the price difference can be calculated. In the beginning of each month where the Raskin is distributed, it can be sure that many of the donations are Raskin. Therefore, the term Raskin for local society can be also called "donation rice" because of its function for donation instead of consumption. The host will sell the rice after the celebration. Rice is a type of food donation with high selling power and it can be sold faster compare to other food types even if the quality is usually very low and sometimes it is not suitable to consume. This rice will continue to circulate from one donation to another and it is almost 
never been consumed. In the end, rice is the only symbol of social legality for women from lower economy to be involved in a social relationship.

As stated by Mauss (1992), to give and receive a gift is the initial step to have social relationship and build social ties. Whereas, referring to instrumental rationality of Weber (Ritzer 2008), if the donation is given directly in form of money, it will have more use value for the receiver and economically profitable. Some social calculations are put forward in basing the act of women for choosing rice as the general form of donation. First, traditionally, rice has stable exchange value and is protected from inflation. Therefore, the amount of rice, 2 to $2.5 \mathrm{~kg}$, does not change much over times. Many donations in form of non-rice are calculated with rice price equivalence to repay the donation (Hefner 1983; Kutanegara 2002). Second, rice is the main consumption of villagers so it will continue to be available and useful; therefore, the reselling price is higher compare to other donation goods. Third, rice is the stereotype of women work, which is processing the rice to be consumed by their family members. For women from underprivileged household, as long as they have rice any other foods will not be a problem. The importance of rice for rural household makes it important donation goods.

As the aforementioned, rice is the general goods for donation. However, women from the host's relatives or close neighbors usually give non-rice food (egg, cooking oil, noodle, coconut, sugar, etc) and lawuh wedang. Lawuh wedang is ready to consumed foods as the side dish in the reception. Socially, donation in form of nonrice food and lawuh wedang are more valuable than rice, even though the price is the same. The reason is that for villagers, rice is a basic need, while non-rice food and lawuh wedang represent the increase or improvement of consumption; therefore, they have higher social value. In other words, a gift in form of non-rice food is better than rice. Gift in form of non-rice food and lawuh wedang have important meaning for the host. Through these gifts, reciprocity principle in rural society can be seen and they are also useful for various interests, especially to entertain the guest and as return gift. Entertaining the guests with food is the key sign of acceptance, hospitality and friendship (Harbottle, 1997) and traditionally, this is the duty of women from the production (processing) to the distribution of the foods. Principle of giving and receiving, or reciprocity as the fundamental rule basing a ceremony (Mauss 1992) in the village in turn will be dominated by food exchange ritual.

The importance of food exchange is indicated by the existence of megari who controls the mechanism of reciprocity principle in tradition to donate. Megari works in woman area by controlling and serving women guest who donate foods (rice or non-rice). Megari will distribute the food to entertain the guest, for souvenir, and for anyone who work voluntary (rewang) and when there is any leftover food they will give the food to the neighbors or sell it. Food for souvenir will be based on the type and amount of the donation. What is inside the souvenir is an issue for women who give donation. During their way home from the party, these women will try to look at each other souvenirs and it can turn to a gossip if the souvenir they received is not as they expected. Therefore, not every woman wants to be a megari, because she will be a gossip topic among the neighbors after the party. On the contrary, megari also source for information on the people who give donation, some may give donation that is inappropriate to the norm and some might give more. Megary will then report to the "hostess" about special donation. This report will be a base for the hostess to determine the amount of donation she will give her neighbor when she is having a celebration (mbarang nggawe). Generally, megari does not write the donation but only relay on her memory. For some societies, to write the amount of the donation is considered improper because "calculating" the donation shows a trading character. Even if it is written, it will not be publicized. However, in practice, the term loss/profit often becomes the topic of "gossip" among women in the neighborhood after the party. In this case, the tradition to donate becomes social dynamic for women when reciprocity is considered imbalance. Therefore, reciprocity institution is women institution that controls every behavior of women in the village related to donation. Thus, forms of reciprocity prevailed for rural women are long term (indirect) in form of return donation and short term (direct) in form of souvenir; whereas, for men, the form is only long term. Meanwhile, according to Mauss (1992), to differentiate potlatch and barter, the return gift is not given directly but in unspecified period. Bringing home the souvenir from a party is something that is expected by family, especially the children and it is the duty of a woman; while, man is considered inappropriate to bring back souvenir from a party. The return gift in form of souvenir is a mandatory to be given to people who give donation in a party or celebration.

The existence of Megari represents the importance of reciprocity principle in rural community; every gift has its reciprocity and it should be repaid. Symbolically, return gift (ulih-ulih in Java-Banyumas's term) is an expression of gratitude for attending the party, for the blessing, attention and most importantly for the donation. However, it is almost impossible for rural women to come to a celebration without a gift. Even if they are economically challenge, the pressure from abashment and social sanction is the trigger to involve in tradition to donate. It is common in Asian villages' societies where reciprocity is a fundamental moral principle basing social activities in villages at MuangThai and Philippine. In Philippine, for example, prevails a principle "every service received, either asked or no, should be repaid", where abashment (hiya) and feeling of moral duty (utang na loob) are the 
trigger (Scoot 1974).

\section{Women and Money}

As previously mentioned, there are different pattern of work division based on sexual in donation. Men will give money and women give foods (rice and non-rice). In the history of Javanese rural societies, food donation describes the subsistence ethic of rural women. Foods given were direct products from agriculture or processed by household mother having local characteristics. Almost all food given can be obtained in surrounding area. At that time, it was common that people bring banana from their own garden as donation to their neighbors or relatives. Vegetables and pulses were often used as donation goods as well. Not only is it produced in their village but also it can be used directly as consumption for the guests. Women who work as farmer also had time to prepare all foods to be given.

However, along with industrial development, including agricultural industry, villages were over flown with products from rural area and many women were removed from agricultural sector. Collier (1981) argues that agricultural development policy set by government of New Order known as green revolution in 1970s has caused evolution process in traditional institutional system, which gives limited access for poor farmers and farmer workers in agricultural production system. The green revolution has caused displacement process on women workers especially farmer worker group from labor market. Various institutions has changed (for example, Bawon system (profit sharing between owner and tenant) using ani-ani (a small knife used for harvesting in) were replaced with sickle, Bawon system were changed into Tebasan (a system were produce were bought before harvesting), processing paddy into rice using huller), since the revolution add more works for men workers. Sajogyo (1985) clearly explain that green revolution has reduced employment opportunity in agricultural sector for women in rural areas. In addition, according to Suratiyah (1991), this situation in turn, pushed rural women to look for job alternative outside agricultural sector. Some of them became migrant labor (women workers), housemaid, trader, factory workers, etc.

The shift of women's work from farm to non-farm in some extent has affected the tradition to donate, because many of them had to leave their home to work. Therefore, time allocation for domestic work is decreased. The market products, which are more practical, replaced food donation that was once using subsistence product. The change from subsistence products to market products surely needs more money. Economically, the change of women's work from farm to non-farm made women to gain more stable income compare to their husband who works in agricultural sector, in which his income will depend on the yield of seasonal harvest. Thus, many of their daily household needs were placed on the woman's income, though quantitatively, the amount is less. This made their income small is because they are not accustomed to "appreciate their own merit" or even to demand minimum wage standard, especially for them who work in private sector (as housemaid). Their awkwardness to money culture affects their inconvenience to donate money, even if this money donation has institutionalized. There are many social considerations for women who are unable to adapt with money donation, which are:

1) They do not always have enough cash; therefore it is more likely for them to be in debt in a food stall to buy rice than to borrow money from their neighbor. A food stall will not sell well if it does not allow for debt;

2) Donation for poor women is social legality to shows their existence as villager whom sometimes marginalized. By donating food, their social legality is under control because it is shown what they bring (keton gawane). Social legality is also under control because women who donate come in groups carrying donation bag typical of the village; in other words, many people see them carrying the goods for donation. It is also under control through Megari mechanism;

3) Direct use philosophy (a celebration at the village is dominated by food redistribution activities);

4) Generally, donation in form of money for women is considered having low trust.

As it is shown in Figure 1, donation in form of money is given directly to hostess without process of control mechanism of megari. Therefore, in women opinion, "there are fraudulence" in the amount of the donation. Fraud in their opinion is less amount of donation (under the standard of village norm). This opinion shows that donation is not based on sincerity but appropriateness. Donation in form of money is given directly to the "hostess" as they shake hands to leave home; thus, the amount of money is unknown. Therefore, the souvenir for people who donate money is treated equally; they are usually given foods from global market (mostly instant noodle from certain brand).

Therefore, reciprocity principle conducted by women in rural areas through food donation (especially rice) is a compromise rationality action accommodating all social actions from Weber, rational and irrational. The reason is that rice fulfills all aspects of exchange value: symbolic value, utility value and exchange value. In other word, rice has social, economic and time dimensions. In this context, it can be concluded that women in rural areas can play in both social rationality (moral) and economic rationality (formal) areas. Rice has symbolic value since food donation is a symbol of specific donation of rural societies (especially women) and this has social control mechanism (through Megari). The utility value of food 
donation is based on the function of the donation that have social solidarity value, which is to provide food for the guests, as souvenir for the guest (women guests), and to be distributed to the neighbors, family or everyone who assist during the ceremony. Whereas, the economic value of food donation (rice) is that rice can be resold after the ceremony to cover all ceremony's expenses. Therefore, food donation generally has market exchange value and rice is a reciprocity medium that is considered to have a stable exchange value. By doing this, women are able to maintain social solidarity amid their economic limitation.

\section{CONCLUSION}

Unlike urban society in general, where donation to a celebration is representing one household unit, in rural society, donation to a celebration is individual; husband and wife donate separately and there exist work division which is sexually dichotomy. Man gives money and woman gives food (rice and non-rice). The existence of food as the exchange tool for donation by women in rural area describes their economic moral that still bound with subsistence ethic. Through food donation, women can share to each other, create sodality space, and strengthen their social legality as villager. Meanwhile, though donation in form of money has institutionalized in various other areas, underprivileged women consider it as socially less valid. In addition, it is considered to have lower trust and inappropriate with moral ethic which has been institutionalized among Javanese rural women.

With the change of donation from gift to money in urban society, rural women still prefer food as the main donation exchange tool. The existence of Megari shows the legacy of traditional society on subsistence economic system, where the role is as a medium of food barter in the tradition to donate. Through megari, food donation (rice and lawuh wedang) is controlled and valued to fulfill reciprocity principle. Through this food donation, women build social solidarity to share to each other, because this donation will be redistributed through megari. It is just that the foods are no longer produced in subsistence way but through market production. The disappearance of local food production can be related to the shift in women's work from farm to non-farm, which leads women to leave their home. Therefore, pragmatism value is put forward in the choice of food, especially instant noodle. Women's work in non-farm sector has shifted value rationality of women to instrumental rationality in terms of food choice, though generally, they cannot accept money as direct social exchange tool. On the other hand, the persistence of food (though it is obtained through market economic) as social exchange tool is mostly due to the social calculation. Food has social control (through the control mechanism of megari); therefore, it allows women to have social legality. Social legality has important meaning as social guarantee for underprivileged women who often marginalized.

Reciprocity of rural women is reciprocity based on food redistribution, either short term (gift replies) or long term (donation reciprocity). Therefore, the general conclusion of the research is that rural monetization has directed moral ethic of women in rural areas in nyumbang tradition to the form of rationality action compromising between rational and irrational actions to maintain food-based social solidarity.

\section{Conflict of Interests}

The author have not declared any conflict of interests.

\section{REFERENCES}

Abdullah I (2001). Seks, Gender dan Reproduksi Kekuasaan. Yogyakarta: Tarawang,

Belshaw CS (1981). Tukar Menukar Tradisional dan Pasar Modern. Jakarta: PT Gramedia.

Camerer (1988). "Gifts as Economic Signals and Social Symbols" dalam Am. J Sociol. 94

Carruthers BG (2005). "Sociology Of Money And Credit", Chapter 16, in Neil J. Smelser and Richard Swedberg (Editors), The Handbook of Economic Sociology (Second Edition), New York: Russell Sage Foundation.

Geertz H (1983). Keluarga Jawa, Jakarta: PT Grafiti Press.

Geertz C (1983). "Culture and Social Change: The Indonesian Case" Man.19:511-532.

Hadihardjono GS (2011). "Tuna Satak Bathi Sanak" on paguyubanjateng.blogspot.com, posting on April 252011.

Harbottle L (1997). "Fast Food/Spoiled Identity" in Food, Health and Identity, London: Routledge.

Hefner RW (1983). The Problem of Preference: Economic and Ritual Change in Highlands Java, Man, New Series 18:4. US: Royal Anthropological Institute- JSTOR

Husken F (1998). Masyarakat Desa dalam Perubahan Zaman: Sejarah Diferensiasi Sosial di Jawa 1830 - 1980, PT Gramedia Widiasarana Indonesia, Jakarta.

Koentjaraningrat (1980). Sejarah Teori Antropologi I, Jakarta: UI-Press.

Komter AE (2005). Social Solidarity and The Gift. New York: Cambridge University Press

Kutanegara PM (2002). "The Role and Meaning of Donation in Rural Societies", Bulletin of Demographic Research and Policies, POPULASI 13:2. Center for Demographic Research of UGM. Yogyakarta.

Mauss M (1992). The Gift, Forms and Function Exchange in Archaic Societies (Terjemahan). Jakarta: Yayasan Obor Indonesia.

Molm LD (2010). The Structure of Reciprocity. Social Psychology Quartely http://spq.sagepub.com/content/73/2/119.abstract

Ritzer G, Douglas JG (2008). Teori Sosiologi: Dari Teori Sosiologi Klasik Sampai Perkembangan Mutakhir Teori Sosial Postmodern (Terjemahan Nurhadi), Kreasi Wacana, Yogyakarta

Sahlins M (1974). Stone Age Economics, Tavistock Publications, London

Sayogyo P (1985). Peranan Perempuan dalam Perkembangan Masyarakat Desa, CV Rajawali, Jakarta

Simmel G (2004). Philosophy of Money - Third Enlarged Edition. Edited by David Frisby. London: Routledge

Stoler A (1977). Class Structure and Female Autonomy in Rural Java. Women and National Development: The Complexities of Change 
3(1):74-89.

http://www.jstor.org/discover/10.2307/3173080?uid=2\&uid=4\&sid=21 104049305931

Suratiyah K (1991). Pembangunan Pertanian dan Peranan Perempuan di Pedesaan Yogyakarta dan Bali, Pusat Penelitian Kependudukan Universitas Gadjah Mada, Yogyakarta. http://books.google.com.ng/books?id=Dec_AAAAMAAJ\&q=Suratiyah $\& d q=S u r a t i y a h \& h l=e n \& s a=X \& e i=6-$

fpU5G2MOnb7AbtqYDoDw\&ved=0CDoQ6wEwBQ
Polanyi K (1957). "The Economy as Instituted Process." 29-53 in The Sociology of Economic Life. Edited by Granovetter, Mark and Richard Swedberg. Boulder, CO: Westview. http://irows.ucr.edu/cd/courses/281/readings/polanyi.pdf

Prasetyo YE (2012). Pertukaran Sosial di Pedesaan: Studi Kasus Komersialisasi Gantangan di Tiga Desa Miskin Subang - Tesis Program Studi Sosiologi Pedesaan, Sekolah Pascasarjana, Instititut Pertanian Bogor. 